\title{
Analysis of a Residential Photovoltaic-Thermal (PVT) System in Two Similar Climate Conditions
}

\author{
Madalina Barbu ${ }^{1,2, * \mathbb{D}}$, George Darie ${ }^{1}$ and Monica Siroux ${ }^{2}$ (D) \\ 1 Department of Power Production and Usage, University Politehnica of Bucharest, \\ 060042 Bucharest, Romania \\ 2 INSA Strasbourg ICUBE, University of Strasbourg, 67000 Strasbourg, France \\ * Correspondence: madalinaioanabarbu@gmail.com; Tel.: +40-741-551-818
}

Received: 23 July 2019; Accepted: 18 September 2019; Published: 20 September 2019 updates

\begin{abstract}
Photovoltaic-thermal (PVT) panels combine solar thermal and photovoltaic technologies and generate simultaneously both heat and electricity. This paper looks at the potential of integrating these systems into small domestic prosumer households for the climates of Bucharest, Romania, and Strasbourg, France. First, some brief background information on PVT systems and the concept of prosumers is introduced, highlighting their features as well as the solar energy market setting in Romania and France. Next, a PVT system is proposed for a given household consumer in Strasbourg and Bucharest with the variable weather conditions corresponding to the two locations. The PVT system and the coupled consumer are modelled in TRNSYS (v17, Thermal Energy System Specialists, Madison, USA). A performance analysis is carried out in order to establish the daily instantaneous energy output and the annual energy production. The results indicate a $10-12 \%$ better performance in Bucharest compared to Strasbourg due to slightly better weather conditions. The system efficiency was assessed through various methods (first law efficiency and primary energy saving). Depending on the method used, the location and time of year, the results vary from $15 \%$ for the first law efficiency to $90 \%$ for the primary energy saving efficiency. The most suitable efficiency assessment method for this study was found to be the primary energy saving method, as it takes into account the regional differences in energy production. This study concludes that the Romanian PVT market has a good potential for adopting the technology, especially since it is currently less mature than in France.
\end{abstract}

Keywords: renewable energy; solar energy; photovoltaic-thermal; micro-cogeneration; prosumer

\section{Introduction}

Solar energy is the most wide-spread type of renewable energy, due to its multiple benefits: It is easily available in many locations, has low operational costs and can be adapted to small, decentralized systems. In theory, there is sufficient solar radiation reaching the Earth to meet 10,000 times the current energy needs of the world [1].

The established solar technologies currently available on the market can be broadly classified into photovoltaic (PV) panels and passive solar-thermal panels (ST). Hybrid photovoltaic-thermal systems (PVT) combine these two technologies and maximize their benefits into one single piece of equipment, producing both electricity and useful heat (Figure 1). PVT systems are a type of micro-cogeneration technology that can be very efficiently integrated into individual households. This can achieve decentralized production of clean heat and energy, maximizing the South facing available space and obtaining an overall better payback of the investment, compared to separate side-by-side PV and ST systems [2]. 


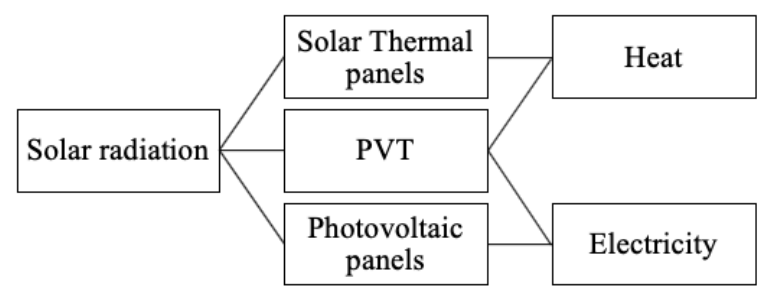

Figure 1. Schematic diagram of the functioning principle of solar-thermal (ST), photovoltaic (PV) and photovoltaic-thermal (PVT) systems.

The current social trend of environmental responsibility, combined with the various financial incentives available for renewable energy (Feed-in Tariffs, Green Certificates), lead to an increasing number of individual consumers that wish to produce and utilize their own energy ('prosumers'). On this market there is a great potential for introducing the PVT technology in order to meet their energy demand with clean and on-site produced heat and power.

Residential PVT systems and their applications in various climate conditions have been of research interest in the past years, with multiple reviews and state of the art papers on this topic [3,4]. A study has been carried out to assess the performance of building integrated PVT (BIPVT) compared to simple building integrated PV (BIPV) in the context of New Delhi, India [5], and also to analyze various types of PV cells: Mono-crystalline and amorphous silicon. It was found that although the first was more efficient, the latter is more economical for the regional context. Another study [6] compares the performance of PVT panels in Athens, Munich and Dundee, and, as expected, Athens offers the most promising conditions. Similar to Romania, the PVT market in Greece is still under development and offers great opportunity for development. An experimental study [7] also carried out for India, showed that PVT system performed better than the simple PV and solar panels, which reinforces the interest for further developing the PVT technology.

This paper uses the software TRNSYS to simulate and analyze the energy output and performance of PVT panels in a small sized prosumer household, comparing two different climate conditions: Bucharest, Romania, and Strasbourg, France. The continental temperate climates are not the ideal locations for PVT systems, as it can be noticed from the literature, and more arid and hot areas are preferred. However, there can be a potential growing market even in colder locations. An interesting comparison can be carried out between France, where the market is developed and there are several manufacturers and distributers of PVT products available, and Romania, where the market is under-developed. Another novelty of this study is related to the explicit TRNSYS model which is analyzed by two performance indicators: First law efficiency and primary energy saving efficiency.

\section{Residential Prosumers and the Energy Market}

A particularly important growing market for renewable energy is the individual self-consumers (households or businesses). Self-consumption represents the production and utilization of energy on-site, which is the most efficient way of using renewable sources. Decentralized systems have the advantage of generating power where it is needed, and are more efficient in terms of transportation losses, since the consumer is close to the energy source. They are also more flexible, offer independent access in remote places and can benefit from localized smart micro-grids. An emerging term for these self-producers is 'prosumers', which is a combination of 'producer' and 'consumer'. More and more consumers are inclined to produce their own clean energy on-site by using renewable sources, driven by various motivations:

- Independence from the regulated grid and safety against fluctuating energy prices;

- Energy losses and transport costs are reduced;

- Financial benefits from subsidies such as green certificates and 'Feed in Tariffs'. 
The PVT systems were investigated and proved efficient for hot tropical climates, in both experimental numerical studies [8,9]. Currently, in Europe there is also an active interest in the research and development of PVT systems. The International Energy Agency (IEA) has carried out the research project Task 35 PV-Thermal Solar Systems [10], which aimed to catalyze the development and adoption of competitive high-quality and commercial systems and to contribute towards internationally accepted standards on performance, testing, and monitoring of commercial PVT. In May 2018 a new PVT research platform, Task 60-PVT Systems: Application of PVT Collectors and New Solutions in HVAC Systems, part of the Solar Heating and Cooling Program, was launched, with 13 states testing innovative technologies, focusing on HVAC solutions [11]. Overall, Task 60 project of the IEA has identified a total of 98 modules in Europe, of which 54 are available on the market, 32 are stopped from production and six are under R \& D [12].

Both the Romanian and French markets are interesting contenders for the integration of the PVT, for two different reasons. In Romania, the solar energy market is growing, with $1.37 \mathrm{GW}$ of PV energy installed at the end of 2017 [13] and $110 \mathrm{MW}_{\text {th }}$ of solar thermal capacity [14]. However, the PVT market has not yet emerged, with only a couple of distributors identified on the market, which gives the opportunity of further exploiting this niche. In France, the market for PV is growing even more, with $875 \mathrm{MW}$ of new installations in 2017, reaching to a cumulative capacity of $8.04 \mathrm{GW}$ [15]. The solar thermal market capacity is not as impressive as the PV, but still significantly higher than Romania: 1.64 $\mathrm{GW}_{\text {th }}$ in 2018 [16]. PVT panels have been introduced on the French marked since 2013, having one of the lead market producer companies, DualSun [17] (Figure 2). The consumers are already familiar with the product and are more willing to adopt it in their green buildings than in Romania.

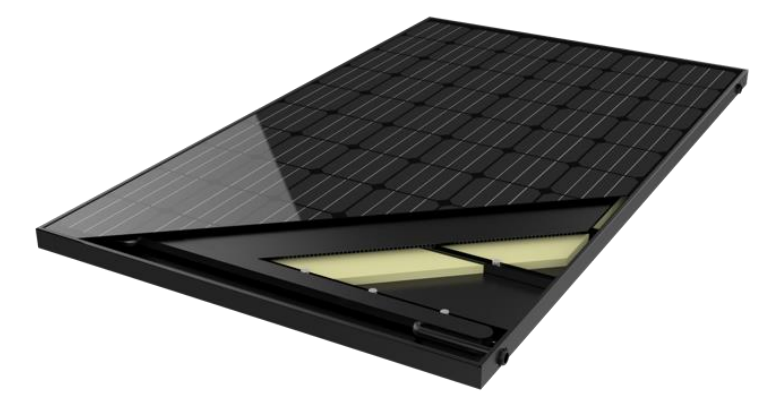

Figure 2. Example of a typical PVT panel from DualSun manufacturer [17].

\section{PVT Systems}

Hybrid PVT systems benefit from a number of performance advantages compared to their individual solar thermal and photovoltaic counterparts:

- The electrical efficiency of PV cells decreases with a temperature coefficient of $0.3-0.9 \% /{ }^{\circ} \mathrm{C}$ above the standard test condition (STC) of $25^{\circ} \mathrm{C}$. Thus, the PV cells in hybrid PVT systems show an energy efficiency of 4-12\% higher compared to the same cell in an individual PV panel [18], due to the fact that the cell is cooled through the extraction of the thermal energy.

- A significant amount of the Sun's spectral emissivity on a PV panel is lost in the form of heat (either by non-absorption or thermalization) (Figure 3). This heat can be recovered and used for domestic hot water (DHW) or heating applications, which leads to increasing the spectrum of operation of the panels and improving the rate of solar energy conversion.

- The global efficiency of the system is increased by combining the electrical and thermal components, since the global efficiency can be described as the sum between the electrical and thermal efficiency of the system, as shown in Equation (1). Furthermore, PVT reaches a higher reduction of the non-renewable primary energy as well as a higher production of solar thermal energy compared to the two separate systems (PV and ST) [19].

$$
\eta_{G L}=\eta_{E L}+\eta_{T H}
$$


- In urban locations, where South facing roof and façade space are limited, this solution is ideal for fulfilling or partially contributing towards the heating and electricity needs of the consumer. In addition, the costs associated with transport, installation, and maintenance are significantly reduced by implementing a single piece of equipment instead of two separate ones.

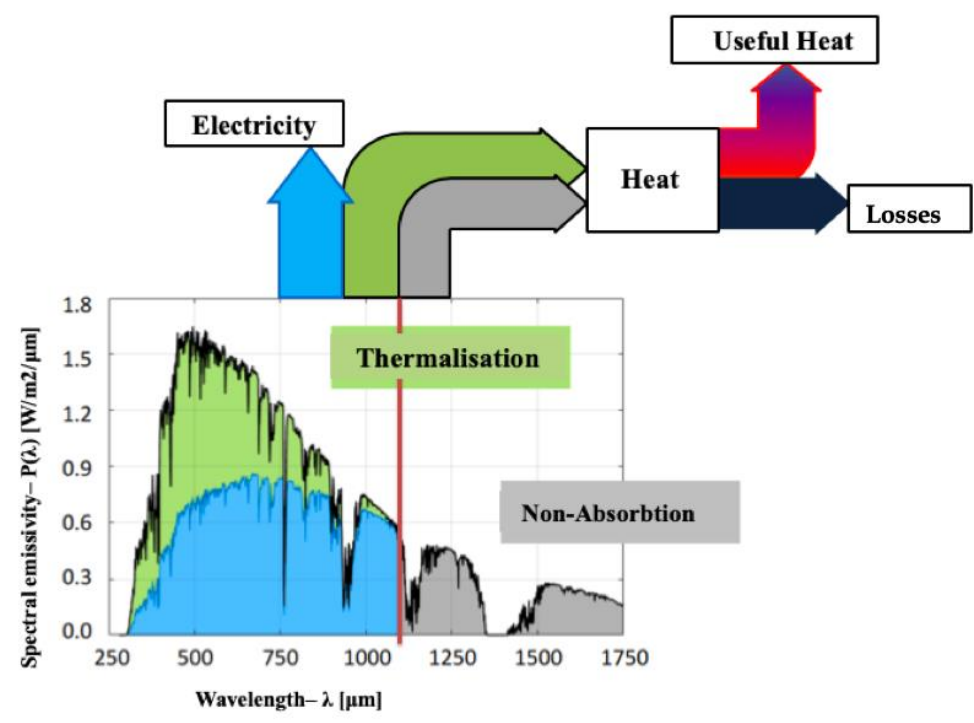

Figure 3. Energy flow diagram of a PVT system: The blue area represents the energy that can be extracted as electricity, the grey area represents the photons with a low level of energy that are unable to excite the electrons to the conduction band and are lost through non-absorption, the green area represents the excess energy that is lost as heat and the red line represents the band-gap of Si.

The PVT system can be configured in multiple ways: Flat or concentrated, with a liquid, air or dual liquid-air working fluid. The geometry of the thermal collector can also take multiple forms (harp, spiral, direct flow, fractal) and can be designed by various manufacturing methods (sheet and tube, roll bond, rectangular channels). Aste et al. [4] carries out a comprehensive review on the various geometrical, thermo-physical, and manufacturing solutions for PVT systems. The configuration investigated in this study is illustrated in Figure 4.

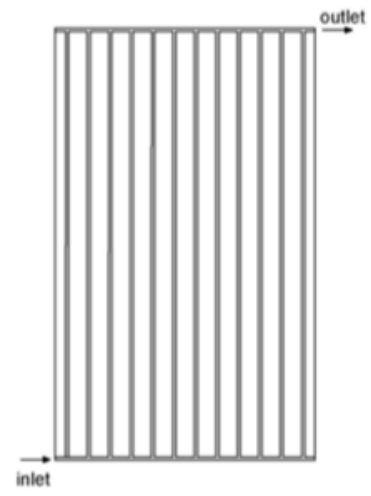

(a)

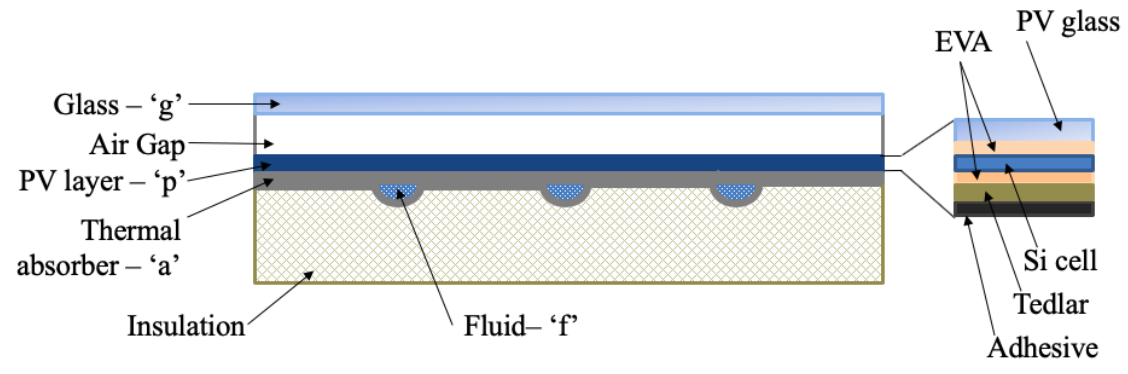

(b)

Figure 4. PVT configuration: (a) Direct flow collector geometry; (b) cross section of the PVT collector [20].

The model developed for this study is a water-based PVT system, with a direct flow geometry of the collector (Figure 4a), roll bond channels (Figure 4b), and mono-c-Si PV cells. The water-based exchanger was chosen due to its better heat transfer capacity compared to air-based systems, and in order to fulfill the domestic hot water (DHW) needs of a prosumer household. The direct flow geometry 
of the channels provides optimal experimental performance and geometrical simplicity [4]. The roll bond channels are thermally efficient, easy to produce, relatively inexpensive and very flexible in terms of geometry [4]. The c-Si PV cells are the most widely used on the market, with the mono-crystalline cells providing better efficiency than the poly-crystalline cells.

\section{Methodology}

\subsection{PVT System}

The PVT system modelled in this paper is illustrated in Figure 5. The system comprises of a PVT collector connected to a water storage tank through a heat exchanger, a circulation pump, connection to the household water main and an inverter/regulator with a battery bank. The input in the system is the meteorological data: Solar irradiation $\left(\mathrm{G}\left(\mathrm{W} / \mathrm{m}^{2}\right)\right)$, ambient temperature $\left(\mathrm{T}_{\mathrm{amb}}\left({ }^{\circ} \mathrm{C}\right)\right)$ and wind speed $(\mathrm{W}(\mathrm{m} / \mathrm{s}))$. The temperature at the outlet of the collector is $T_{\text {out_coll, }}$, the temperature of the tank is $\mathrm{T}_{\text {tank}}$, the temperature of the water main that feeds the tanks is $\mathrm{T}_{\text {main }}$, and the temperature at the inlet of the collector is $\mathrm{T}_{\mathrm{in} \_ \text {coll, }}$, all in ${ }^{\circ} \mathrm{C}$. The PVT acts as a pre-heater when the temperature reached by the tank is not sufficient for providing domestic hot water.

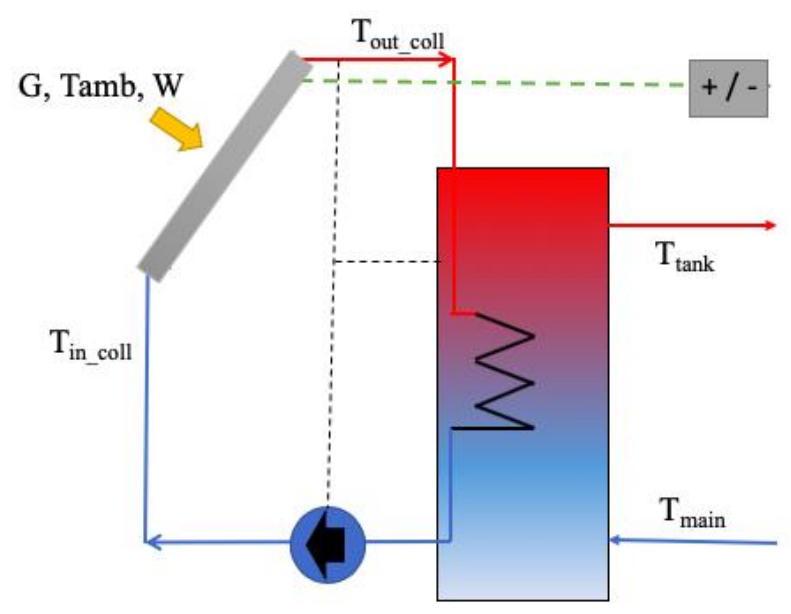

Figure 5. Schematic diagram of the components of the PVT system.

The PVT panel is assumed to be a flat plate collector, with mono-c-Si PV cells and a direct flow roll bond thermal absorber, with the technical characteristics summarized in Table 1.

Table 1. Properties of the PVT panel.

\begin{tabular}{ccc}
\hline Parameter & Value & Unit \\
\hline Collector Area & 6 & $\mathrm{~m}^{2}$ \\
Thermal Efficiency & 70 & $\%$ \\
Electrical Efficiency & 15 & $\%$ \\
Fluid & Water + Glycol & - \\
Thermal loss coefficient for bottom and edge & 20 & $\%$ \\
Slope & 30 & $\circ$ \\
Temperature coefficient of PV & -0.5 & $\% /{ }^{\circ} \mathrm{C}$ \\
Packing factor & 80 & $\%$ \\
\hline
\end{tabular}

\subsection{Meteorological Conditions}

The output of a PVT system is dependent upon three meteorological parameters: Ambient temperature, irradiation, and wind speed. The solar irradiation has the most significant impact on the performance of a PVT system, as it determines the electrical output, but also influences the temperature of the materials through radiative heat transfer. The temperatures in the PVT layers are also dependent on the ambient temperature, through convective and conductive heat transfer processes in the solid 
and liquid layers of the system, but also on the speed of the wind which determines the convective heat losses at the surface and at the back of the panel. The yearly profile of each parameter is obtained from Meteonorm Database.

The total radiation comprises of three components: Direct beam radiation, diffuse radiation, and reflective radiation. Direct radiation is the direct incident beam radiation that hits the surface of the panel, the diffuse radiation refers to the radiation that has been scattered through the molecules of the atmosphere, and reflective radiation (also referred to as albedo) is the radiation reflected by the surroundings.

The meteorological conditions of both Strasbourg, France, and Bucharest, Romania are used in parallel for the simulations. This allows a comparison of the performance of the PVT system in both regions. The climate of Romania can be described as temperate continental, with cold, cloudy winters and frequent snow and fog, and sunny summers with frequent showers and thunderstorms. In the southern region, where Bucharest is located, the winters are milder and the summers hotter. France's climate is temperate, with four specific regions. Alsace, where Strasbourg is located, is characterized by a continental climate which harbors cold winters and hot summers. Although, in broad terms, both cities have a similar climate (hot summers and cold winters), there are some small differences in the average values of the meteorological parameters, which are summarized in Table 2.

Table 2. Climate characterization of Strasbourg and Bucharest (source: WMO-World Meteorological Organization).

\begin{tabular}{|c|c|c|c|c|c|c|}
\hline & & $\begin{array}{l}\text { Winter } \\
\text { (Dec-Feb) }\end{array}$ & $\begin{array}{l}\text { Spring } \\
\text { (Mar-May) }\end{array}$ & $\begin{array}{l}\text { Summer } \\
\text { (Jun-Aug) }\end{array}$ & $\begin{array}{l}\text { Autumn } \\
\text { (Sep-Nov) }\end{array}$ & $\begin{array}{c}\text { Annual } \\
\text { Total }\end{array}$ \\
\hline \multirow{2}{*}{$\begin{array}{c}\text { Temperature } \\
\left({ }^{\circ} \mathrm{C}\right)\end{array}$} & Bucharest & 4.0 & 17.8 & 29.1 & 17.4 & 17.1 \\
\hline & Strasbourg & 5.2 & 15.2 & 24.2 & 14.5 & 14.8 \\
\hline \multirow{2}{*}{$\begin{array}{c}\text { Monthly } \\
\text { rainfall (mm) }\end{array}$} & Bucharest & 36.9 & 48.1 & 64.9 & 47.9 & 594 \\
\hline & Strasbourg & 36.5 & 52.3 & 66.9 & 54.8 & 632 \\
\hline \multirow{2}{*}{$\begin{array}{l}\text { Monthly rainy } \\
\text { days }\end{array}$} & Bucharest & 9.3 & 10.5 & 9.9 & 7.5 & 113 \\
\hline & Strasbourg & 8.4 & 9.8 & 10.2 & 8.9 & 112 \\
\hline \multirow{2}{*}{$\begin{array}{l}\text { Monthly sun } \\
\text { hours }\end{array}$} & Bucharest & 72.6 & 189.7 & 278.8 & 163.0 & 2121 \\
\hline & Strasbourg & 54.5 & 160.3 & 222.0 & 108.7 & 1637 \\
\hline
\end{tabular}

Figures 6 and 7 illustrate a sample of the daily total radiation for a typical summer and winter week, respectively, in Strasbourg and Bucharest. The two cities have a similar average rage of values during the summer days, of $700-900 \mathrm{~W} / \mathrm{m}^{2}$. The daily curve of ambient temperature for the two cities is shown in Figures 8 and 9. It can be observed that summer temperatures are slightly higher in Bucharest compared to Strasbourg, while the Romanian winters are colder. Figures 10 and 11 show the variation of wind speed during the summer and winter periods, respectively. On average, the wind is stronger in Strasbourg, with only a few higher peaks in Bucharest. Overall, the wind and temperature data suggest that the PVT will perform better in Bucharest, while the solar radiation is more or less equivalent.

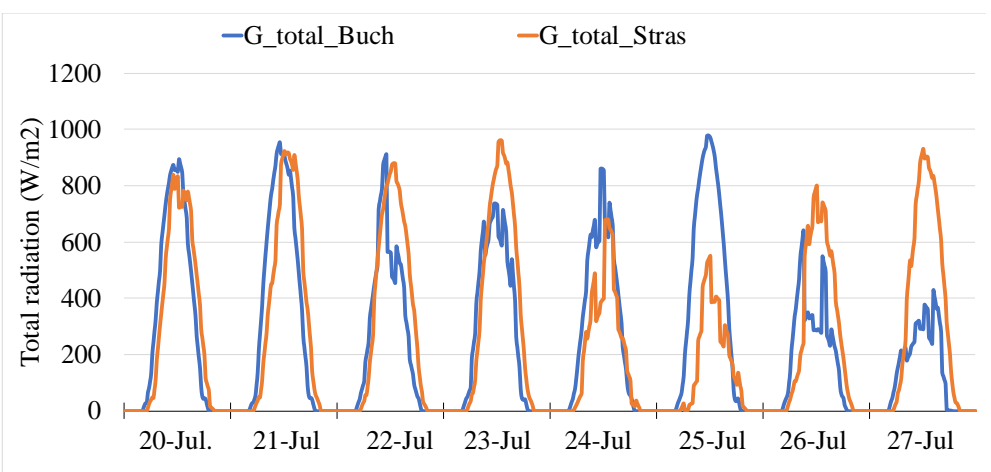

Figure 6. Total solar radiation during a summer period for Bucharest and Strasbourg. 


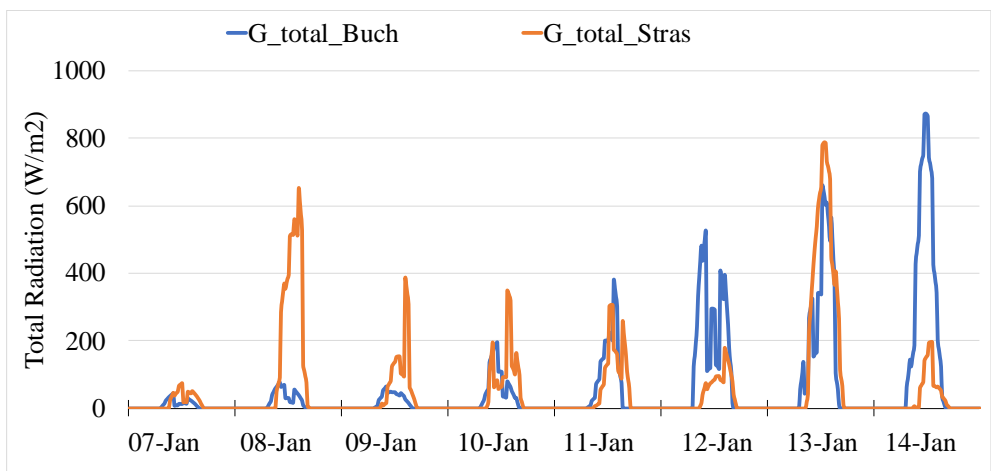

Figure 7. Total solar radiation during a winter period for Bucharest and Strasbourg.

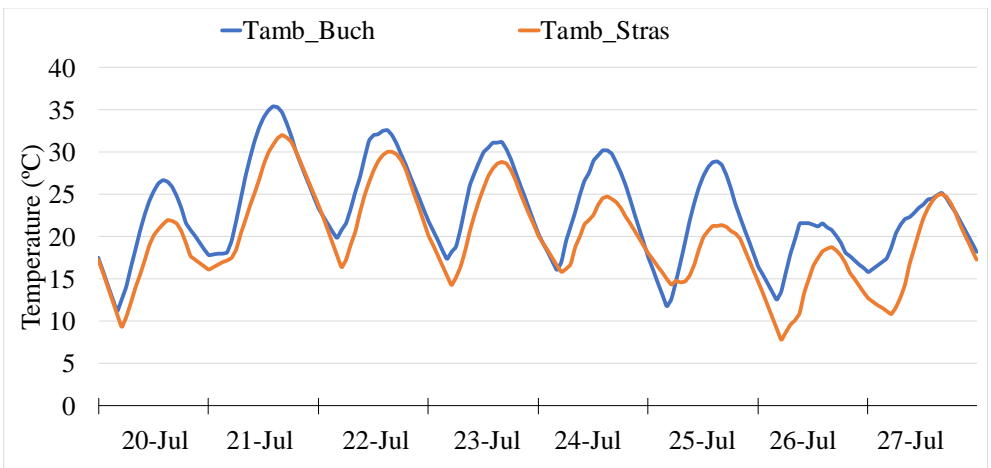

Figure 8. Ambient temperature during a summer period for Bucharest and Strasbourg.

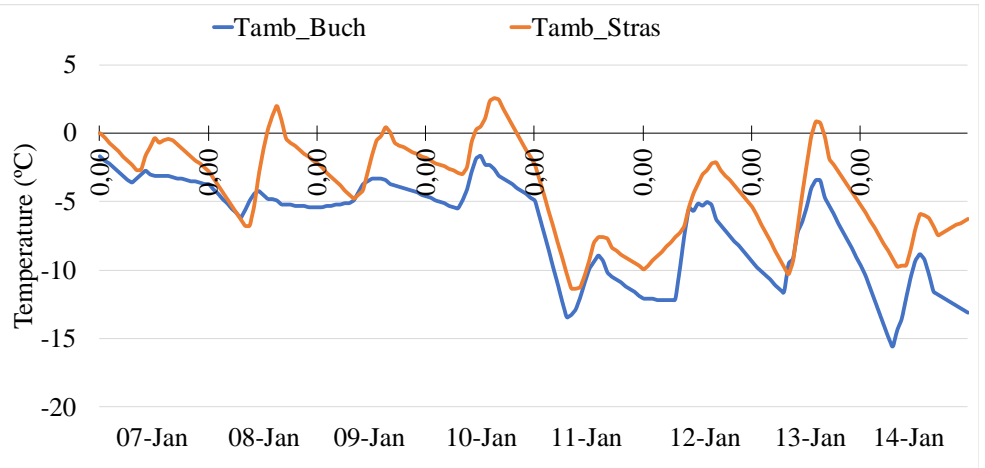

Figure 9. Ambient temperature during a winter period for Bucharest and Strasbourg.

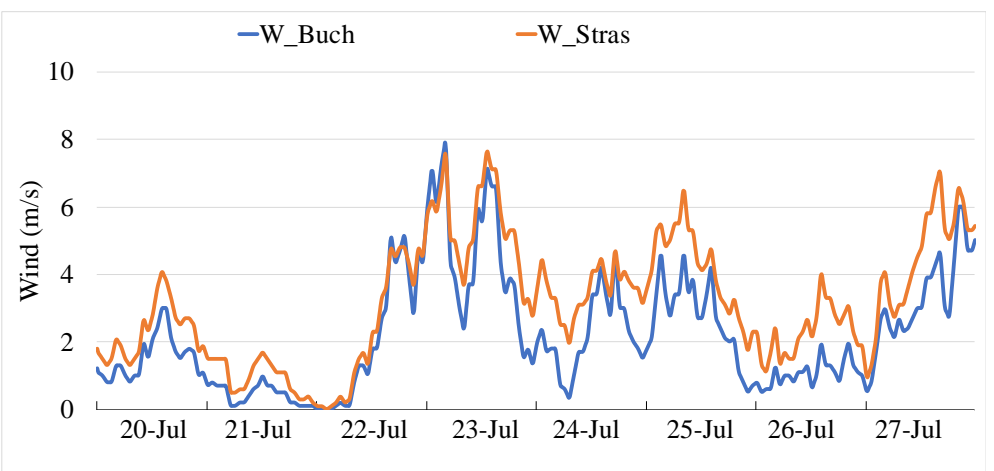

Figure 10. Wind speed during a summer period for Bucharest and Strasbourg. 


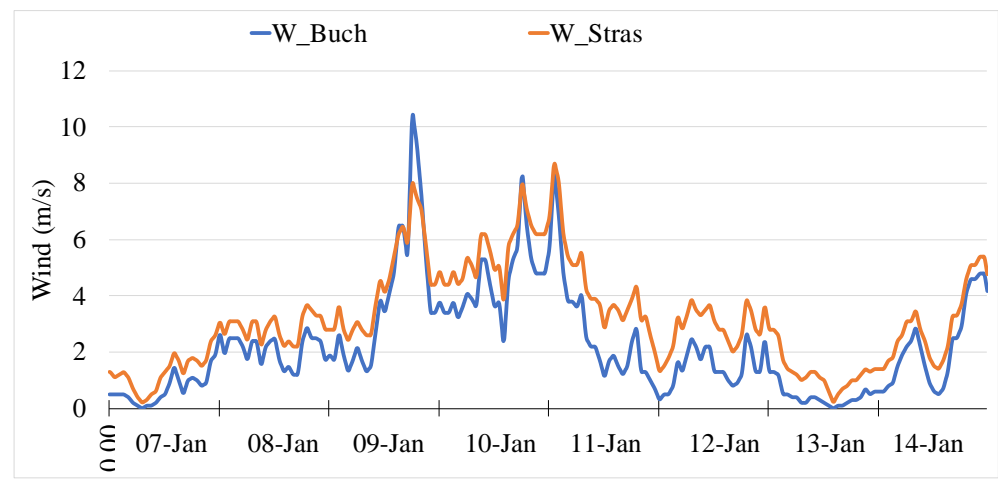

Figure 11. Wind speed during a winter period for Bucharest and Strasbourg.

\subsection{DHW and Electricity Demand}

In order to carry out an accurate simulation, a realistic daily time dependent profile of the household DHW demand is required. The daily profile of DHW is dependent upon various parameters: The number of inhabitants, appliances, ambient conditions, seasonal variations, the average daily hot water volume, and the yearly demand [21].

The profile used for this simulation was created using the DHW-calc software (v1, University of Kassel, Kassel, Germany) developed for the IEA-SHC Task 26, which can generate realistic DHW profiles for European countries for any required period of time and timestep [22,23]. This software has been successfully used and validated in multiple research papers $[21,24,25]$. The user can define a number of parameters, such as the total mean daily water volume, probability distribution, flow rates, holidays, etc. Figure 12 shows an example of a three-day profile with a $1 \mathrm{~h}$ time step resolution for 2001/day average consumption, which was used for this simulation. The profile generated by DHW-calc is different for weekdays and for weekends, and the profile is included in the DHW Load function of TRNSYS, shown in Figure 13.

The temperature level for DHW was set to $45^{\circ} \mathrm{C}$, while the cold water from the main is assumed constant across the year at $10^{\circ} \mathrm{C}$.

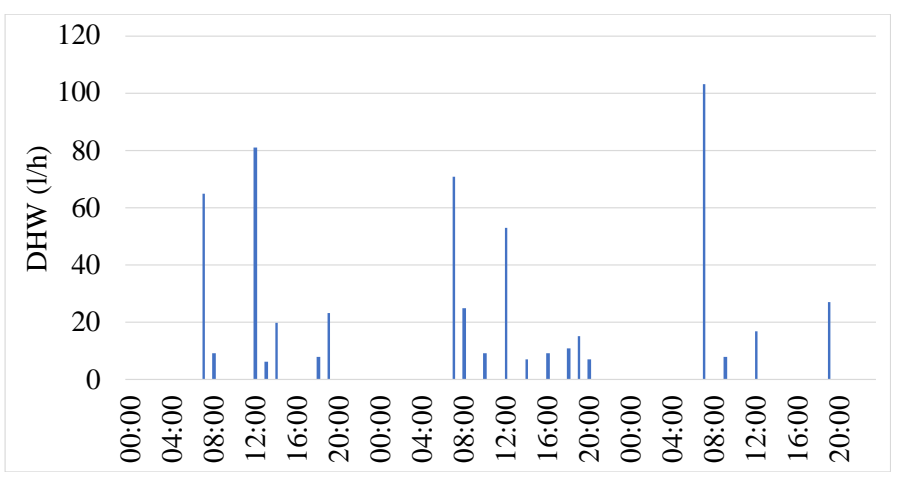

Figure 12. Three-day domestic hot water (DHW) profile generated with DHW-calc.

An electrical demand curve was generated using a forcing function in TRNSYS and considering weekday and weekend variations, as well as holidays, and the system includes a battery bank. The electricity demand also includes the power consumption of the pump for circulating the fluid. The excess of produced electricity is exported to the grid when the battery is full, and when the battery load is less than the demand, electricity is bought back from the grid.

The same DHW and electricity demand profiles were used for both simulations, in Strasbourg and Romania. The DHW profile generated with DHW-calc has been developed to be applicable for any European country, and the electricity demand was also assumed to be similar. This way, a comparison based solely on the input meteorological data can be achieved. 


\subsection{TRNSYS Model}

TRNSYS (transient system simulation tool) is a flexible software that can simulate the behavior of dynamic transient systems. A TRNSYS model was developed to replicate the system in Figure 13, and it includes: Weather Data (Type 15), PVT collector (Type 50), Stratified Storage Tank with a capacity of 1001 (Type 4), Single Speed Pump (Type 114), Inverter/Charge controller (Type 48), a Battery Bank (Type 47) and Controllers (Type 2). The Type 15 component is a tool that reads weather data either from the built-in database or from a user provided spreadsheet, and processes it to provide the input weather data for the simulation (temperature, radiation, wind speed). The storage tank (Type 4) models a tank that can be subjected to thermal stratification, by establishing the number of thermal nodes $\mathrm{N}$. If $\mathrm{N}$ is equal to one, the tank is modeled as fully-mixed with no stratification, which was assumed for the purpose of this study. Type 114 is the component for a constant speed pump that maintains a constant fluid outlet mass flow rate. The pump control strategy modelled by a Type 2 component is based on the temperature of the liquid in the storage tank and the DHW demand. The collector pump circulates water from the tank when the energy can be collected, and the tank is emptied by the DHW load and refilled when it reaches a low volume. Type 48 models both the regulator of the system, which distributes DC power from the solar cell array to and from a battery, and the inverter converts the DC power to AC. The electrical controller decides whether to use the electrical load for charging the battery or for meeting the demand. Type 47 models the battery bank of the system, which is based on a lead-acid type of battery and can output data on the variation of the state of charge over time and the rate of charge or discharge.

The simulation assumes that no heat losses occur on the pipes, the optical properties of materials are constant and no surroundings partial shading or dust is considered. The electrical flow is shown with purple arrows, the liquid flow in blue and the dotted arrows connect the control circuit and energy demand. The PVT component has eight operational modes, which vary the method of calculation for the thermal loss coefficient and transmittance-absorptance factor. This model used mode four, which calculates the parameters according to definitions of Klein (1976) [26].

The numerical model behind the PVT collector (Type 50) has been developed based on the work of Florschuetz [27], using the Hottel-Whillier-Bliss equations. Starting from the steady state energy balance of a system:

$$
\frac{d^{2} T}{d x^{2}}=\frac{1}{k \delta}\left[U_{L}\left(T-T_{a}\right)-S+q_{e}\right]
$$

where $T\left({ }^{\circ} \mathrm{C}\right)$ is the temperature of the element $d x, k$ is the thermal conductivity $(\mathrm{W} / \mathrm{mK}), \delta$ is the thickness of the element $(\mathrm{m}), U_{L}$ is the thermal loss coefficient $\left(\mathrm{W} /\left(\mathrm{m}^{2} \cdot \mathrm{K}\right)\right), T_{a}$ is the ambient temperature $\left({ }^{\circ} \mathrm{C}\right), S$ is the absorbed solar energy $(\mathrm{W})$ and $q_{e}$ is the electrical output $(\mathrm{W})$, the paper defines the useful thermal output of the PVT collector as:

$$
Q_{u}=A_{c} F_{R}\left[S-U_{L}\left(T_{f, i}-T_{a}\right)\right]
$$

where $A_{c}$ is the area of the collector $\left(\mathrm{m}^{2}\right), F_{R}$ is the heat removal factor (-) and $T_{f, i}$ is the inlet temperature of the fluid $\left({ }^{\circ} \mathrm{C}\right)$. The electrical output of the system is defined as:

$$
Q_{e}=\frac{A_{c} S \eta_{a}}{\alpha}\left\{1-\frac{\eta_{r} \beta_{r}}{\eta_{a}}\left[F_{R}\left(T_{f, i}-T_{a}\right)+\frac{S}{U_{L}}\left(1-F_{R}\right)\right]\right\}
$$

where $\eta_{a}$ is the efficiency of the cell at ambient temperature (\%), $\alpha$ is the effective absorbance of the cell $(-), \eta_{r}$ is the reference cell efficiency (\%) and $\beta_{r}$ is the temperature coefficient of the cell (\%/K).

The temperature at the outlet of the collector can be approximated as:

$$
T_{f, o}=T_{f, i}+Q_{u} A_{c} /\left(V_{\text {flow }} \rho c_{f}\right)
$$

where $V_{\text {flow }}$ is the volumetric flow in the collector $\left(\mathrm{m}^{3} / \mathrm{s}\right), \rho$ is the fluid density $\left(\mathrm{kg} / \mathrm{m}^{3}\right)$ and $c_{f}$ is the heat capacity of the collector fluid $(\mathrm{J} /(\mathrm{kg} \cdot \mathrm{K}))$. 
This model is a simplified version of a complete numerical dynamic analysis that can be performed on a PVT based on the heat transfer in each layer of the panel [20,21], where a system of ordinary differential equations is solved simultaneously to find the temperatures at any time of the simulation. The detailed models are used for in-depth layer analysis and geometrical, optical or thermo-physical optimizations and sizing. For the purpose of a quantitative analysis of overall daily, weekly and annual production of energy, the TRNSYS Type 50 model was validated and proved accurate.

The PVT component requires a set of input parameters that depend on the specific PVT that is to be modelled. These can be found in the manufacturer's specifications and refer to: Collector fin efficiency, plate absorbance, number of glass covers, optical efficiency, collector plate emittance, loss coefficient, temperature coefficient, STC temperature, and packing factor. Thus, the module can be customized to replicate a product available on the market.

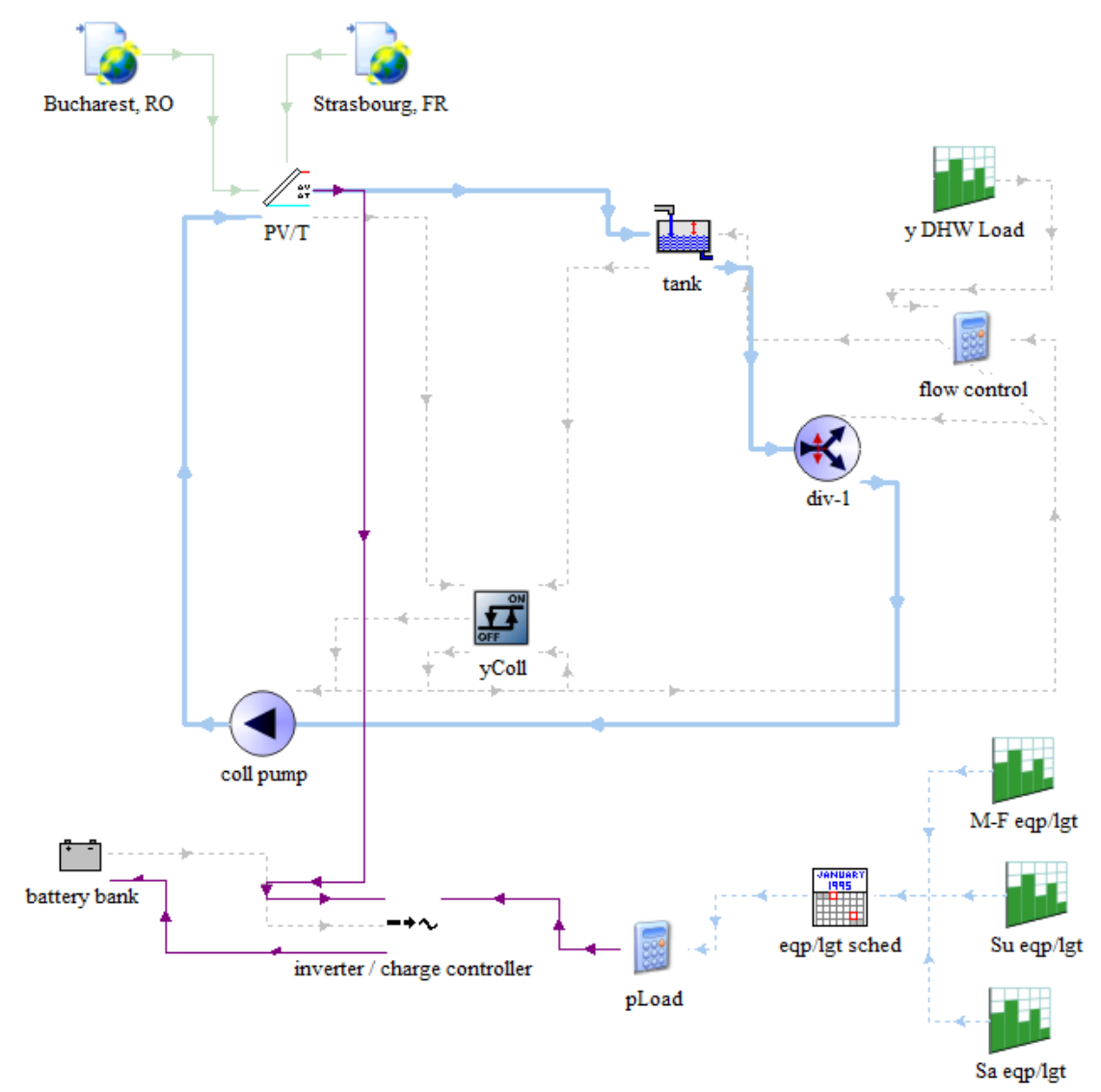

Figure 13. Components of the transient system simulation tool (TRNSY) model.

\subsection{System Performance}

The energy performance of the system can be computed in terms of thermal, electrical, and overall efficiencies $\left(\eta_{T H}, \eta_{E L}, \eta_{\text {overall }}\right)$. The electrical efficiency is calculated as the ratio between the power generated by the system $\left(P_{E L}\right)$ and the amount of solar radiation incident on the surface of the collector $\left(A x G_{i r r}\right)$ :

$$
\eta_{E L}=\frac{P_{E L}}{A G_{i r r}}
$$

The standard equation for thermal efficiency is represented by the ratio between the amount of thermal energy generated by the system $\left(Q_{T H}\right)$ and the solar radiation incident on the surface of the collector $\left(A x G_{i r r}\right)$ :

$$
\eta_{T H}=\frac{Q_{T H}}{A G_{i r r}}=\frac{\dot{m} c_{f}\left(T_{f-o u t}-T_{f-i n}\right)}{A G_{\text {irr }}}
$$


where $\dot{m}$ is the mass flow rate of the fluid $(\mathrm{kg} / \mathrm{s})$ and $c_{f}$ is the specific heat capacity $(\mathrm{J} /(\mathrm{kg} \cdot \mathrm{K}))$, which in this case for Glycol water $40 \% / 60 \%$ is $3600 \mathrm{~J} /(\mathrm{kg} \cdot \mathrm{K})$.

Another definition for the thermal efficiency was proposed by Bombarda et al. [28]. Here, a distinction is made between the electrical and thermal power of the system, and thus the electrical power production is subtracted from the total incident irradiation. This definition allows for a more accurate comparison between the thermal performance of a PVT and stand-alone solar thermal system.

$$
\eta_{T H}^{*}=\frac{Q_{T H}}{A G_{i r r}-P_{E L}}=\frac{\dot{m} c_{f}\left(T_{f-o u t}-T_{f-i n}\right)}{A G_{i r r}-P_{E L}}=\frac{\eta_{T H}}{1-\eta_{E L}}
$$

From the point of view of the first law of thermodynamics, the global efficiency of the system $\left(\eta_{G L}\right)$ can be calculated as the sum of the thermal and electrical efficiencies. This is also known as the first law efficiency:

$$
\eta_{G L}=\eta_{E L}+\eta_{T H}
$$

Another approach is to consider the difference in grade between the two types of energy, i.e., electrical energy is a higher form of energy compared to the thermal. Thus, due to the fact that a $\mathrm{kW}_{\mathrm{el}}$ cannot be directly compared to a $\mathrm{kW}_{\mathrm{th}}$, some authors [19,29] propose the primary energy saving efficiency $\left(\eta_{P E S}\right)$ as a more accurate way of assessing the performance of the system:

$$
\eta_{P E S}=\eta_{T H}+\frac{\eta_{E L}}{\eta_{T \text { power }}}
$$

where $\eta_{\text {Tpower }}$ is the average efficiency of producing electrical power, and it depends on the country of reference. On average, it can be assumed to be 0.4 [19]. For Romania, the average efficiency of producing electrical power in 2016 was 0.532, while in France it was 0.601 [30]. These values were used for computing the primary energy saving efficiency in Section 5.

\section{Simulation Results}

The detailed simulations were run for the two significant one-week periods of summer and winter (7 Jan-13 Jan and $20 \mathrm{Jul}-26 \mathrm{Jul}$ ) and for both the meteorological conditions of Bucharest and Strasbourg, with a 15-minute time step. In addition, an annual simulation was performed to determine the weekly electrical and thermal energy production for the duration of a year.

The electrical power output of the system for summer and winter is illustrated in Figures 14 and 15, respectively. The variation in the output follows closely the variation in solar radiation. The ambient temperature also has an effect on the power output: As the operating temperature increases, the efficiency of the PV cells drops.

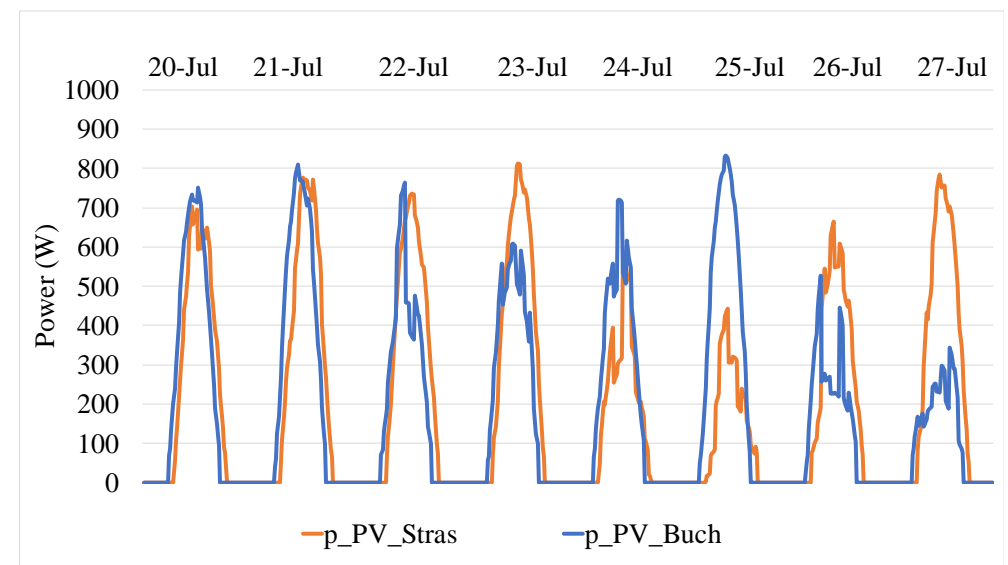

Figure 14. Instantaneous electrical power generated by the system during the summer. 


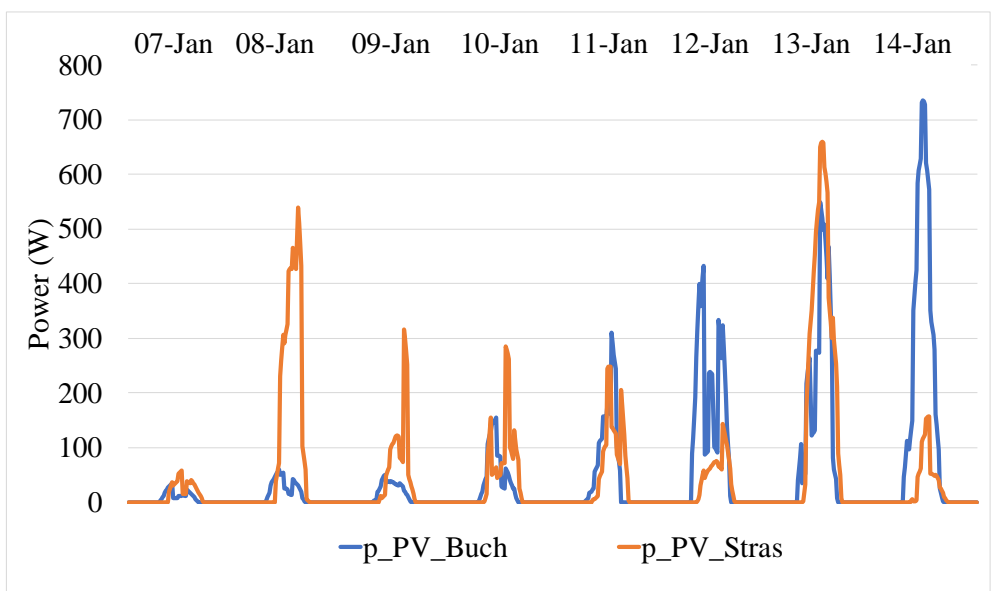

Figure 15. Instantaneous electrical power generated by the system during the winter.

Figures 16 and 17 show the evolution of the temperature at the outlet of the collector $\left(\mathrm{T}_{\text {out_coll }}\right)$ and the temperature of the storage tank $\left(\mathrm{T}_{\text {tank }}\right)$ for summer and winter in Strasbourg and Bucharest. During winter, the tank reaches a maximum of $15^{\circ} \mathrm{C}$, while during summer the maximum is around $30{ }^{\circ} \mathrm{C}$.

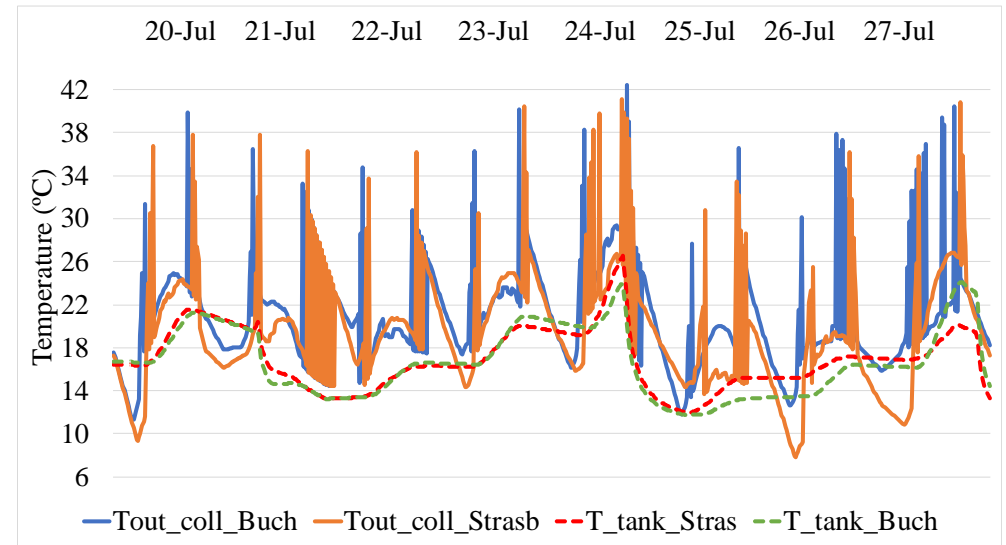

Figure 16. Temperature of the collector tank during summer.

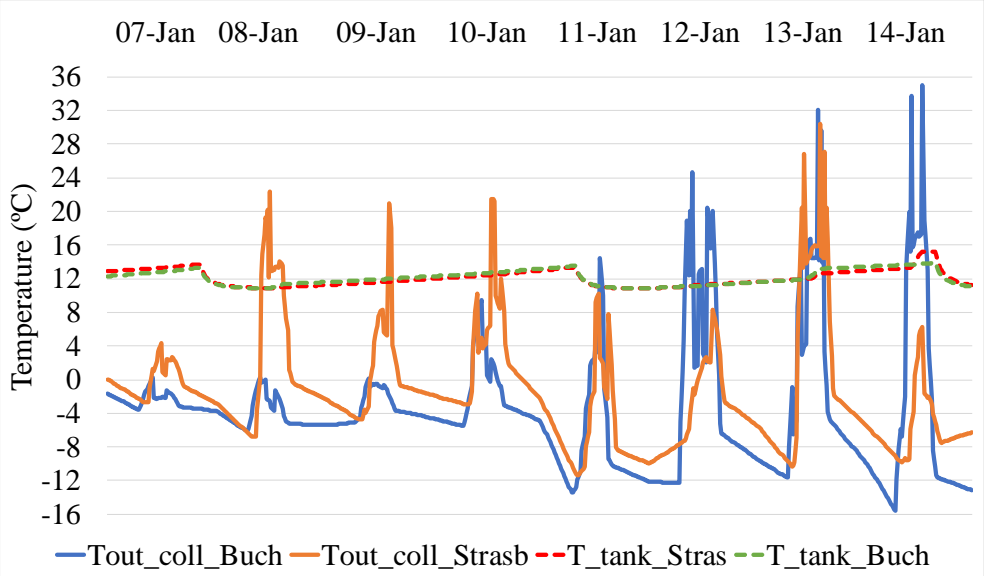

Figure 17. Temperature of the collector tank during winter. 
Over a year, the weekly average temperature and solar radiation for Bucharest and Strasbourg are illustrated in Figure 18. The solar radiation was averaged for the non-zero values, from sunrise to sunset. Given these conditions, the thermal and electrical energy outputs are illustrated in Figure 19. Overall, the annual energy produced by the system in the two cities is summarized in Table 3. Assuming an annual energy consumption of $2000 \mathrm{kWh}$ and a thermal energy for DHW of $6000 \mathrm{kWh}_{\mathrm{TH}}$, the table also shows the percentage of coverage for the household. It can be observed that the system performs better under the meteorological conditions of Bucharest, where it is capable of covering more than $50 \%$ of the annual consumption.

The results indicate that a $6 \mathrm{~m}^{2}$ system would operate well in both climates, but with a 10-12\% better performance in Bucharest. The climatic conditions in Bucharest are more suitable (higher radiation and temperature) during the summer but worse during the winter. The overall effect shows a slight advantage of PVT systems in Bucharest compared to Strasbourg.

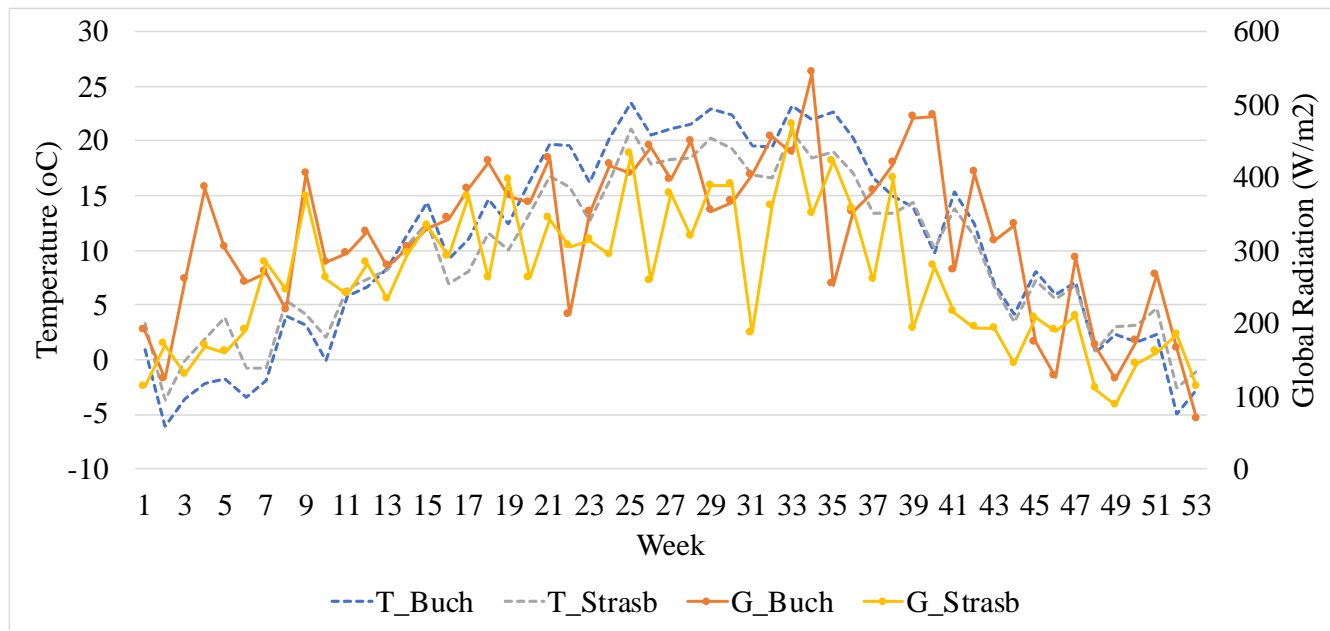

Figure 18. Weekly average temperature and solar radiation for a period of one year.

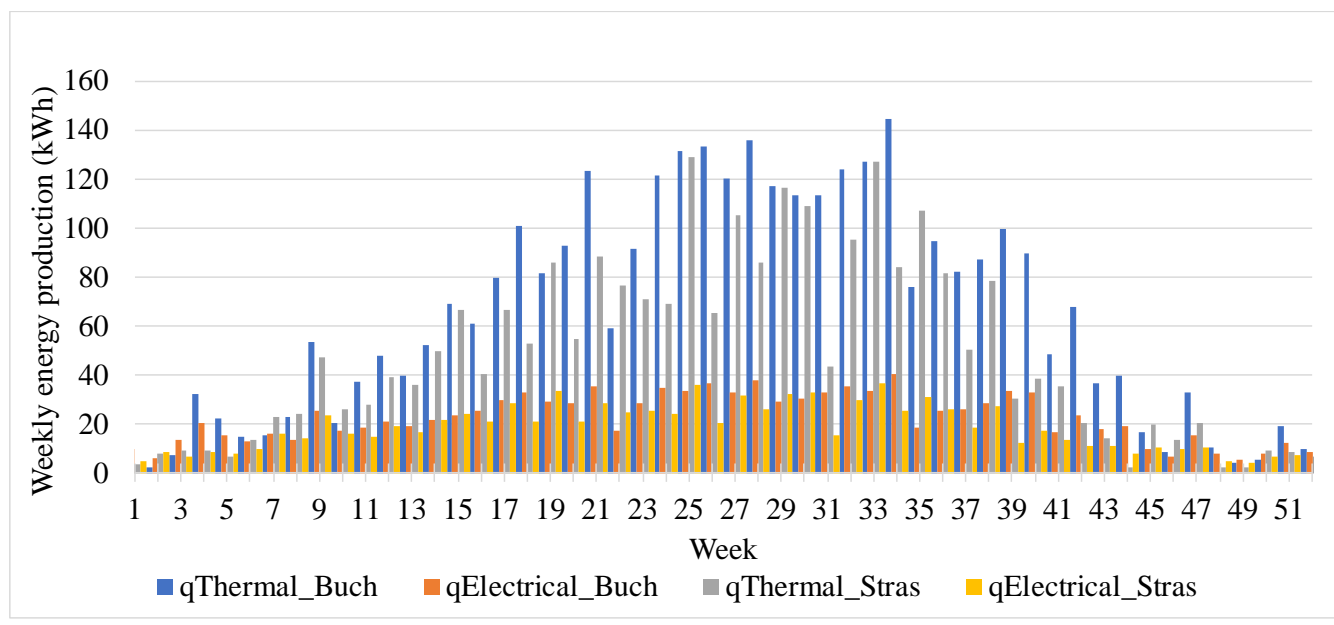

Figure 19. Weekly energy production for a period of one year.

Table 3. Total annual energy output for the two locations.

\begin{tabular}{ccc}
\hline Energy & Total Annual Output & Percentage of Total Consumption \\
\hline Thermal energy in Bucharest & $3340.80 \mathrm{kWh}_{\mathrm{TH}}$ & $55.68 \%$ \\
Thermal energy in Strasbourg & $2491.96 \mathrm{kWh}_{\mathrm{TH}}$ & $41.53 \%$ \\
Electrical energy in Bucharest & $1173.24 \mathrm{kWh}_{\mathrm{EL}}$ & $58.66 \%$ \\
Electrical energy in Strasbourg & $962.52 \mathrm{kWh}_{\mathrm{EL}}$ & $48.13 \%$ \\
\hline
\end{tabular}


Another investigated topic is the efficiency of the system in terms of electrical, thermal, and global performance. As discussed in Section 4.5, the system performance can be described in multiple ways: First law efficiency and primary energy saving efficiency. The thermal efficiency was computed according to Equation (8), by subtracting the electrical power from the total incident irradiation. The weekly efficiency of the system is calculated by taking into account the total weekly energy production (shown in Figure 19) and the total energy received from the sun to the surface of the panel during that week.

Figure 20 illustrates the weekly electrical and modified thermal efficiency of the system. It can be observed that the electrical efficiency in both cases slightly drops during the summer, due to the increase in the operating temperature of the cells, while the thermal efficiency is at its maximum during the summer weeks, reaching 64\% in Bucharest and 55\% in Strasbourg. In addition, Table 4 summarizes the monthly energy production and efficiencies for both locations, for a better comparison. The monthly values of the energy production are calculated by adding the weekly production illustrated in Figure 19, and the efficiency values are obtained by averaging the weekly values shown in Figure 20.

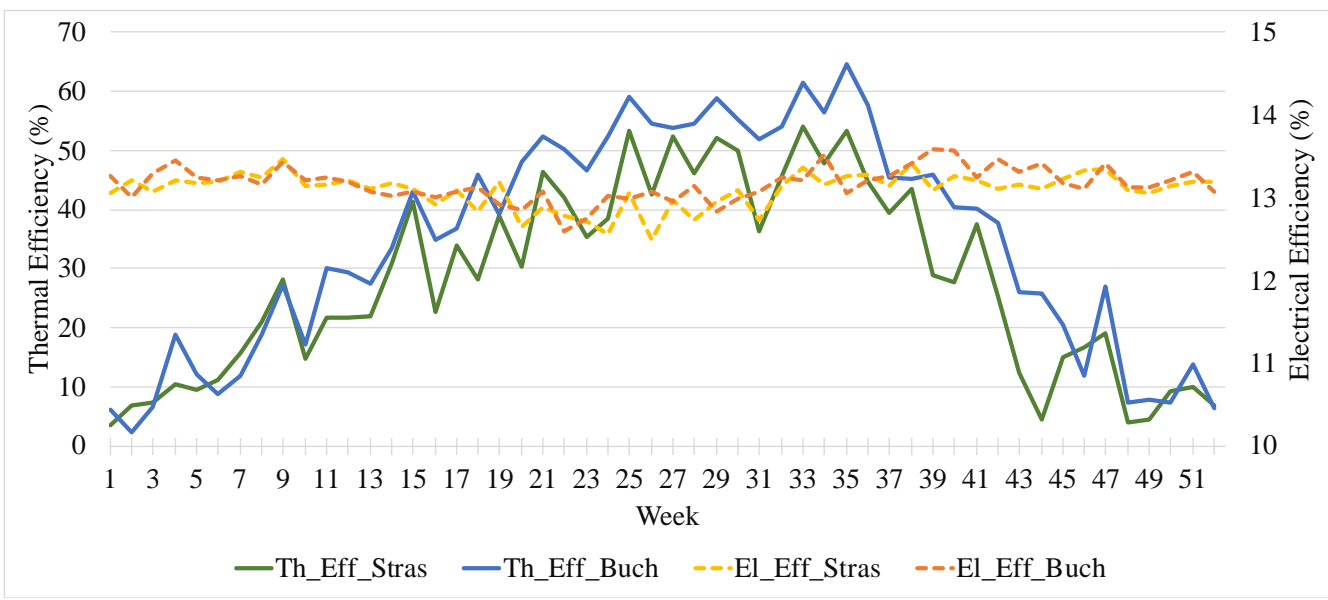

Figure 20. Weekly electrical and thermal efficiency for a one-year period.

Table 4. Monthly summary of energy production and efficiency.

\begin{tabular}{|c|c|c|c|c|c|c|c|c|}
\hline Month & $\begin{array}{c}\text { Thermal } \\
\text { Energy } \\
\text { Buch } \\
\left(\mathbf{k W h}_{\mathrm{TH}}\right)\end{array}$ & $\begin{array}{l}\text { Thermal } \\
\text { Energy } \\
\text { Strasb } \\
\left(\mathbf{k W h} \mathbf{h}_{\mathrm{TH}}\right)\end{array}$ & $\begin{array}{c}\text { Electrical } \\
\text { Energy } \\
\text { Buch } \\
\left(\mathbf{k W h}_{\mathrm{EL}}\right)\end{array}$ & $\begin{array}{c}\text { Electrical } \\
\text { Energy } \\
\text { Strasb } \\
\left(\mathbf{k W h} \mathbf{L L}_{\mathrm{EL}}\right)\end{array}$ & $\begin{array}{l}\text { Thermal } \\
\text { Efficiency } \\
\text { Buch } \\
(\%)\end{array}$ & $\begin{array}{c}\text { Thermal } \\
\text { Efficiency } \\
\text { Strasb } \\
(\%)\end{array}$ & $\begin{array}{c}\text { Electrical } \\
\text { Efficiency } \\
\text { Buch } \\
(\%)\end{array}$ & $\begin{array}{c}\text { Electrical } \\
\text { Efficiency } \\
\text { Strasb } \\
(\%)\end{array}$ \\
\hline Jan & 60.88 & 39.74 & 56.75 & 32.14 & 9.24 & 7.57 & 13.25 & 13.14 \\
\hline Feb & 117.75 & 110.44 & 75.76 & 67.26 & 20.87 & 20.18 & 13.25 & 13.27 \\
\hline Mar & 171.10 & 153.78 & 87.20 & 77.60 & 27.49 & 22.20 & 13.15 & 13.16 \\
\hline Apr & 336.05 & 250.27 & 122.32 & 105.41 & 39.92 & 32.99 & 13.04 & 13.03 \\
\hline May & 402.33 & 341.51 & 123.80 & 120.49 & 47.26 & 38.56 & 12.83 & 12.84 \\
\hline Jun & 551.34 & 402.70 & 152.30 & 124.47 & 54.84 & 46.55 & 13.03 & 12.76 \\
\hline Jul & 541.23 & 402.44 & 147.21 & 121.03 & 54.87 & 46.01 & 13.05 & 12.92 \\
\hline Aug & 503.31 & 447.15 & 135.44 & 134.38 & 57.03 & 47.79 & 13.25 & 13.24 \\
\hline Sept & 382.56 & 214.26 & 129.13 & 82.09 & 55.74 & 46.69 & 13.20 & 13.09 \\
\hline Oct & 184.72 & 73.76 & 78.71 & 46.98 & 41.83 & 32.55 & 13.45 & 13.21 \\
\hline Nov & 55.33 & 48.44 & 35.58 & 29.09 & 15.18 & 12.33 & 13.28 & 13.23 \\
\hline Dec & 42.65 & 36.05 & 34.11 & 24.78 & 9.49 & 6.93 & 13.17 & 13.13 \\
\hline
\end{tabular}

All the global performance indicators described in Section 4.5 were computed and are described in Figure 21. The first law efficiency is simply the sum of the thermal and electrical efficiencies illustrated in Figure 20. Overall, a better performance in Bucharest can be easily observed. The efficiency calculated by the PES method is higher than the first law efficiency, reaching $90 \%$ for operation in Bucharest. Due to the fact that the average efficiency of producing electrical power in Bucharest is 
lower than in Strasbourg (0.532 compared to 0.601), the difference between the two cities in terms of PES increases further compared to the first law efficiency, which can be observed in the graph. The overall trend follows closely the trend of the thermal efficiency in Figure 20, with high values during the summer and low during the winter. The inverse variation of the electrical efficiency is insignificant and does not affect the general trend.

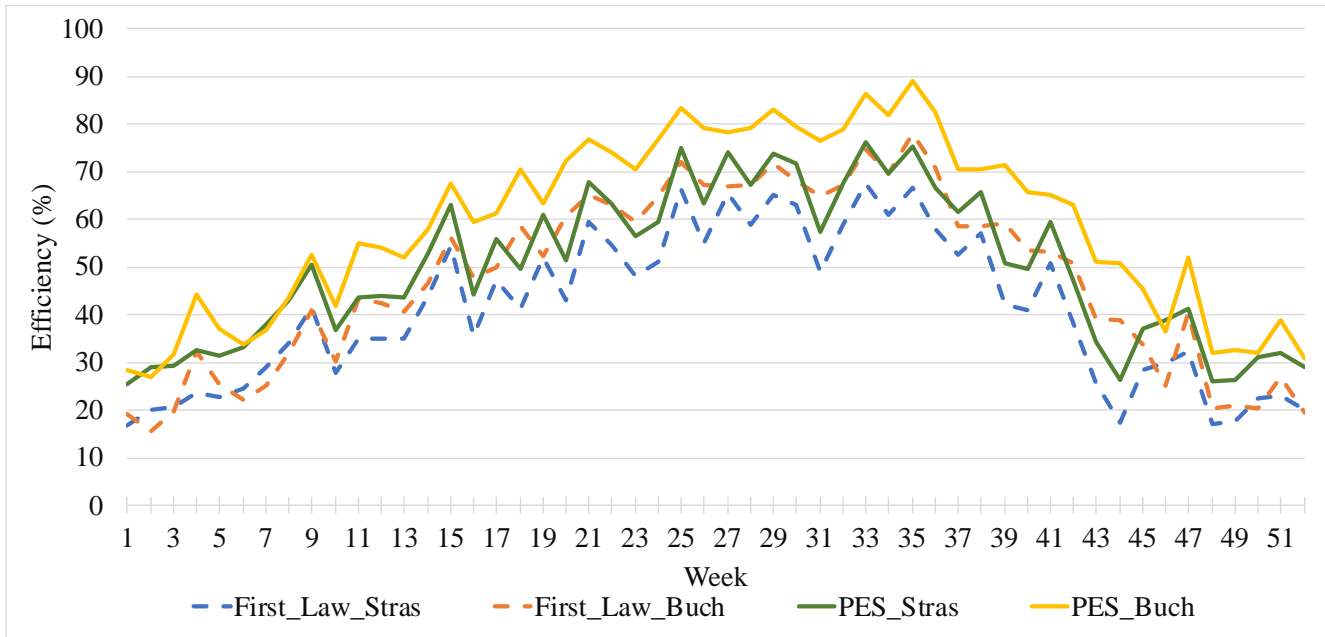

Figure 21. Weekly overall efficiency.

\section{Discussion}

The system presented in this paper couples a typical residential household with a PVT system that generates both heat and electricity, in two similar climate conditions. According to the meteorological data, the two cities, Bucharest and Strasbourg, have similar overall weather patterns with hot summers and cold winters. However, there are some small dissimilarities in terms of wind speed, average ambient temperature, and total irradiation which would indicate that Bucharest is a more suitable location for achieving the best PVT performance. The simulations were run for representative seven-day summer and winter periods to assess the electrical power, temperature in the storage tank, and the temperature of the working fluid, and also for a yearlong period to assess the global annual performance. As expected, the electrical performance flows closely the global irradiance with little influence from the ambient temperature and wind speed. The tank is coupled with a DHW consumer, thus the temperature does not reach high values, even though the fluid at the outlet at the collector can reach up to $43^{\circ} \mathrm{C}$.

Overall, the yearly production of electrical and thermal energy, both supported by back-up solutions (battery bank and auxiliary heater respectively), indicates that the energy requirements of an average family household could be half fulfilled over the course of one year, with a slight advantage in the Bucharest climate compared to Strasbourg. This was expected due to the slightly improved weather conditions.

In terms of system performance, there are various ways of assessing it and it is debatable which is the most accurate and suitable method. The first law efficiency is the simplest and widely used method, where there is no distinction made between the electrical and thermal power. The Primary Energy Saving efficiency takes into account the regional differences in energy production, and can be more useful to compare the efficiency of the system in two different locations, as is the case of this study.

Some of the limitations of this simulation and its results are: The simplicity of the PVT model compared to a full finite element analysis, the fact that all the components are pre-defined in the TRNSYS software and thus a full customization is difficult, the consumer profiles were obtained by means of forcing functions and statistical methods and can vary significantly according to the individual end user and the location of the system. 


\section{Conclusions and Perspectives}

This paper has performed a dynamic simulation of a PVT system for a small size domestic household using the software TRNSYS. The system includes both thermal and electrical storage, and is coupled to the simulated electrical and DHW demand of the household. The results show that, with a battery storage system, the household demand can be $58 \%$ covered in Bucharest and $48 \%$ in Strasbourg. The hot water heating system, provided that an auxiliary heater is utilized, can also be covered $51 \%$ and $41 \%$, respectively.

Overall, it appears that small scale PVT is a promising solution for maximal harvesting of the solar energy. Residential prosumers are the target market of this technology, which is quickly developing in the Western European countries, but is lagging behind in the East. More public awareness and demonstrative projects providing proof of concept are required to further push this technology on the mainstream market, next to conventional PV and solar thermal.

An analysis of the costs, profitability, and return period of the system would be an interesting direction for further research, including consideration of the $\mathrm{CO}_{2}$ emission savings, from the cradle to the grave of the panel. This can be proved challenging due to the fluctuating market prices of energy, a non-homogeneity in the quoted prices of PVT on the market and the difficulty in accurately accounting for the true costs of $\mathrm{CO}_{2}$ emissions. Another issue to be further investigated is the coupling of the PVT panels with heat pumps for a more efficient utilization of the thermal energy and assessing the cost-benefits compared to those of a simple PVT system. This analysis can be carried out for a number of different consumer profiles, not only residential households, but also office buildings, schools and hospitals, and the system optimized to fit the demand curve. Finally, an energetic study of the PVT system would also be an interesting research direction.

Author Contributions: M.B., M.S. and G.D. all contributed in the conceptualization. The methodology and software implementation were done by M.B. G.D. obtained the data resources. M.B. prepared the original draft. Final editing was done by all authors.

Funding: This research received no external funding.

Conflicts of Interest: The authors declare no conflict of interest.

\section{Abbreviations}

$\begin{array}{ll}\text { PVT } & \text { photovoltaic-thermal } \\ \text { PV } & \text { photovoltaic } \\ \text { ST } & \text { solar thermal } \\ \text { STC } & \text { standard testing conditions } \\ \text { DHW } & \text { domestic hot water } \\ \text { EVA } & \text { ethylene vinyl acetate } \\ \mathrm{c}-\mathrm{Si} & \text { crystalline silicon } \\ \eta & \text { efficiency }(\%) \\ \mathrm{T} & \text { temperature }\left({ }^{\circ} \mathrm{C}\right) \\ \mathrm{k} & \text { thermal conductivity }(\mathrm{W} / \mathrm{mK}) \\ \delta & \text { thickness }(\mathrm{m}) \\ \mathrm{U} & \text { thermal loss coefficient }(\mathrm{W} / \mathrm{m} 2 \mathrm{~K}) \\ \mathrm{S} & \text { solar energy absorbed }(\mathrm{W}) \\ \mathrm{q}_{\mathrm{e}} & \text { electrical energy }(\mathrm{W}) \\ \mathrm{Q}_{\mathrm{u}} & \text { thermal energy }(\mathrm{W}) \\ \mathrm{A} & \text { area }\left(\mathrm{m}^{2}\right) \\ \mathrm{F}_{\mathrm{r}} & \text { heat removal factor }(-) \\ \alpha & \text { effective absorbance }(-) \\ \beta_{\mathrm{r}} & \text { temperature coefficient }(\% / \mathrm{K})\end{array}$




\section{References}

1. EREC. Renewable Energy in Europe, 2nd ed.; EarthScan: London, UK, 2008; 116p.

2. Barbu, M.; Patrascu, R.; Darie, G.; Tutica, D. A technical-economical analysis of the implementation of hybrid solar energy systems in small energy prosumer applications. Qual. Access Success 2019, 20, 134-138.

3. Kumar, A.; Baredar, P.; Qureshi, U. Historical and recent development of photovoltaic thermal (PVT) technologies. Renew. Sustain. Energy Rev. 2015, 42, 1428-1436. [CrossRef]

4. Aste, N.; del Pero, C.; Leonforte, F. Water flat plate PV-thermal collectors: A review. Sol. Energy 2014, 102, 98-115. [CrossRef]

5. Agrawal, B.; Tiwari, G.N. Life cycle cost assessment of building integrated photovoltaic thermal (BIPVT) systems. Energy Build. 2010, 42, 1472-1481. [CrossRef]

6. Axaopoulos, P.J.; Fylladitakis, E.D. Performance and economic evaluation of a hybrid photovoltaic/thermal solar system for residential applications. Energy Build. 2013, 65, 488-496. [CrossRef]

7. Rawat, P.; Dhiran, T.S. Comparative Analysis of Solar Photovoltaic Thermal (PVT) Water and Solar Photovoltaic Thermal (PVT) Air Systems. Int. J. Civil Mech. Energy Sci. 2017, 3, 8-12.

8. Nualboonrueng, T.; Tuenpusa, P.; Ueda, Y.; Akisawa, A. Field Experiments of PV-Thermal Collectors for Residential Application in Bangkok. Energies 2012, 5, 1229-1244. [CrossRef]

9. Rejeb, O.; Dhaou, H.; Jemni, A. Parameters effect analysis of a photovoltaic thermal collector: Case study for climatic conditions of Monastir, Tunisia. Energy Convers. Manag. 2015, 89, 409-419. [CrossRef]

10. IEA SHC Task 35-PV/T-Systems. Available online: http://task35.iea-shc.org (accessed on 8 August 2019).

11. IEA SHC Hadorn. French PVT Market is Picking Up. Available online: http://www.iea-shc.org/article? NewsID=205 (accessed on 8 August 2019).

12. IEA SHC Task 60-PVT Systems: Application of PVT Collectors and New Solutions in HVAC Systems. Available online: http://task60.iea-shc.org (accessed on 20 June 2019).

13. PV Magazine. Romania's PV Capacity Grew by $70 \mathrm{MW}$ in 2017. Available online: https://www.pv-magazine. com/2017/03/08/romanias-pv-capacity-grew-by-70-mw-in-2016/ (accessed on 20 June 2019).

14. Weiss, W.; Spörk-Dür, M. Solar Heat Worldwide; IEA Solar Heating \& Cooling Programme; AEE-Institute for Sustainable Technologies: Gleisdorf, Austria, 2017.

15. PV Magazine. France's PV Hits 8 GW Milestone. Available online: https://www.pv-magazine.com/2018/02/ 28/frances-pv-hits-8-gw-milestone/ (accessed on 22 June 2019).

16. IEA SHC. France Country Report 2018. Available online: http://www.iea-shc.org/country-report-france (accessed on 22 June 2019).

17. Brottier, L. Optimisation Biénergie d'un Panneau Solaire Multifonctionnel: Du Capteur aux Installations in Situ. Ph.D. Thesis, Université Paris-Saclay, Paris, France, 2019.

18. BRE National Solar Centre. Hybrid Solar Photovoltaic Thermal Panels-Low Carbon Heating Technologies; BRE National Solar Centre: London, UK, 2016.

19. Zhou, C.; Liang, R.; Zhang, J. Optimization Design Method and Experimental Validation of a Solar PVT Cogeneration System Based on Building Energy Demand. Energies 2017, 10, 1281. [CrossRef]

20. Barbu, M.; Mey-Cloutier, S.; Siroux, M.; Darie, G. Dynamic modelling and sensibility analysis of a hybrid photovoltaic-thermal (PVT) system. In Proceedings of the 7th European Conference on Renewable Energy Sysstems, Madrid, Spain, 10-12 June 2019.

21. Guarracino, I.; Mellor, A.; Ekins-Daukes, N.J.; Markides, C.N. Dynamic coupled thermal-and-electrical modelling of sheet-and-tube hybrid photovoltaic/thermal (PVT) collectors. Appl. Therm. Eng. 2016, 101, 778-795. [CrossRef]

22. Jordan, U.; Vajen, K. DHWcalc: Program to generate domestic hot water profiles with statistical means for user defined conditions. In Proceedings of the ISES Solar World Congress, Orlando, FL, USA, 8-12 August 2005.

23. Jordan, U.; Vajen, K. Influence of the DHW load profile on the fractional energy savings: A case study of a solar combi-system with TRNSYS simulations. Sol. Energy 2001, 69, 197-208. [CrossRef]

24. Pflugradta, N.; Muntwylera, U. Synthesizing residential load profiles using behavior simulation. In Proceedings of the CISBAT 2017 International Conference-Future Buildings \& Districts-Energy Efficiency from Nano to Urban Scale, Lausanne, Switzerland, 6-8 September 2017. 
25. Kelly, N.; Samuel, A.; Tuohy, P. The effect of hot water use patterns on heating load and demand shifting opportunities. In Proceedings of the BS2015: 14th Conference of International Building Performance Simulation Association, Hyderabad, India, 7-9 December 2015.

26. Klein, S.A. Calculation of flat-plate collector loss coefficients. Sol. Energy 1975, 17, 79-80. [CrossRef]

27. Florschuetz, L.W. Extension of the Hottel-Whillier Model to the Analysis of Combined Photovoltaic/Thermal flat plate collectors. Sol. Energy 1979, 22, 361-366. [CrossRef]

28. Bombarda, P.; Di Marcoberardino, G.; Lucchini, A.; Leva, S.; Manzolini, G.; Molinaroli, L.; Pedranzini, F.; Simonetti, R. Thermal and electric performances of roll-bond flat plate applied to conventional PV modules for heat recovery. Appl. Therm. Eng. 2016, 105, 304-313. [CrossRef]

29. Huang, B.; Lin, T.; Hung, W.; Sun, F. Performance evaluation of solar photovoltaic/thermal systems. Sol. Energy 2001, 70, 443-448. [CrossRef]

30. European Environment Agency. Efficiency of Conventional Thermal Electricity and Heat Production in Europe 2018. Available online: https://www.eea.europa.eu/data-and-maps/indicators/efficiency-ofconventional-thermal-electricity-generation-4/assessment-2 (accessed on 8 August 2019).

C 2019 by the authors. Licensee MDPI, Basel, Switzerland. This article is an open access article distributed under the terms and conditions of the Creative Commons Attribution (CC BY) license (http://creativecommons.org/licenses/by/4.0/). 